\title{
PENGARUH TINDAK KORUPSI TERHADAP KEMISKINAN DI NEGARA-NEGARA ASIA TENGGARA DENGAN MODEL PANEL DATA*
}

\author{
Aditya Firman Baktiar ${ }^{1}$, Herpanindra Fadhilah², Margareth \\ Dwiyanti Simatupang ${ }^{3}$, Mulawarman ${ }^{4}$, Salsavira ${ }^{5}$, dan Rani \\ Nooraeni ${ }^{6} \neq$
}

\author{
1Politeknik Statistika STIS, Indonesia, adityafirmanb@gmail.com \\ 2 Politeknik Statistika STIS, Indonesia, herpanindrafadhilah1@gmail.com \\ 3Politeknik Statistika STIS, Indonesia, mds1708@gmail.com \\ ${ }^{4}$ Politeknik Statistika STIS, Indonesia, rhyuuzaki@gmail.com \\ ${ }^{5}$ Politeknik Statistika STIS, Indonesia, salsvir25@gmail.com \\ 6 Politeknik Statistika STIS, Indonesia, raninoor@stis.ac.id \\ ‡corresponding author \\ Indonesian Journal of Statistics and Its Applications (eISSN:2599-0802) \\ Vol 4 No 2 (2020), 311 - 320
}

Copyright (C) 2020 Aditya Firman Baktiar, Herpanindra Fadhilah, Margareth Dwiyanti Simatupang, Mulawarman, Salsavira, and Rani Nooraeni. This is an open-access article distributed under the Creative Commons Attribution License, which permits unrestricted use, distribution, and reproduction in any medium, provided the original work is properly cited.

\begin{abstract}
Poverty is still being an issue all over the world. It also happens in Southeast Asia that mostly consists of developing countries that identic with high poverty rates. Countries in the world have tried to eradicate the problem of poverty, it's just that it can be hampered due to the high level of corruption. This study aims to look at suitable models and the relationship between corruption and poverty. The data source in this study is secondary data from ten countries in Southeast Asia from 2015 to 2018. Analysis of the data used in this study is panel data. The result obtained is a panel data regression model that is more suitable for modeling the effect of corruption on poverty in Southeast Asian countries is a fixed effect model. Based on the model, the corruption represented by Corruption Perception Index (CPI) and the poverty represented by Human Development Index (HDI) is directly proportional which means every increase in one unit of CPI will also increase the HDI score by 0.001443 unit.
\end{abstract}

Keywords: corruption, poverty, panel data.

\footnotetext{
${ }^{*}$ Received Feb 2020; Accepted Jun 2020; Published online on Jul 2020
} 


\section{Pendahuluan}

Kemiskinan masih menjadi isu yang sering dibahas di negara-negara di dunia. Berdasarkan data yang didapat dari International Labour Organization (ILO), tingkat kemiskinan di negara-negara maju terus meningkat. Kemiskinan tentunya tidak hanya terjadi di negara-negara maju tetapi juga terjadi di negara-negara berkembang. Menurut Bank Dunia, 40\% dari angka kemiskinan global terdapat di negara berkembang. Bahkan saat ini kemiskinan tidak hanya terjadi pada orang yang tidak bekerja, melainkan juga terjadi kepada orang-orang yang bekerja atau yang disebut dengan pekerja rentan. International Labour Organization (ILO) pada tahun 2017 mencatat bahwa pekerja rentan banyak tersebar di negara berkembang dengan lebih dari 300 juta orang yang hanya memiliki pendapatan per kapita kurang dari \$1,9 per hari. Badan Pusat Statistik yang merupakan lembaga penyedia data statistik di Indonesia mendefinisikan kemiskinan dengan menggunakan konsep basic needs approach. Konsep ini memandang kemiskinan sebagai ketidakmampuan untuk memenuhi kebutuhan dasar, baik yang berupa makanan maupun non makan. Jadi penduduk miskin adalah penduduk dengan rata-rata pengeluaran per kapita per bulan di bawah garis kemiskinan. Menurut Suparlan (1993), kemiskinan adalah suatu standar hidup yang rendah karena adanya tingkat kekurangan materi pada sekelompok orang apabila dibandingkan dengan standar kehidupan yang umum berlaku dalam masyarakat.

Di sisi lain, masalah korupsi juga bukan merupakan hal yang baru di masyarakat. Kegiatan penyalahgunaan wewenang untuk mendapatkan keuntungan ini sudah banyak terdengar berbagai kasusnya di media. Korupsi berasal dari bahasa latin yakni corrumpure yang memiliki arti busuk, rusak, menggoyahkan, dan menyogok. Menurut Transparancy International (2020), korupsi merupakan perilaku petinggi publik yang menyalahgunakan kekuasaan yang dimiliki untuk memperkaya diri sendiri dengan cara yang tidak sesuai dengan peraturan yang ada. Korupsi tentunya berdampak buruk bagi negara, contohnya saja di Afrika Selatan, kerugian yang diakibatkan oleh korupsi hingga tahun 2015 mencapai \$ 46 miliar. Menurut Santoso (2011), korupsi juga berdampak kepada runtuhnya moral bangsa, mematikan etos kerja masyarakat, eksploitasi sumber daya alam, dan merosotnya human capital.

Negara-negara di dunia sudah berupaya untuk memberantas masalah kemiskinan, hanya saja hal tersebut terhambat akibat tingkat korupsi yang masih tinggi. Beberapa penelitian pun telah dilakukan, diantaranya penelitian yang dilakukan oleh Chetwynd et al. (2003) yang mengemukakan bahwa terdapat hubungan antara korupsi dengan kemiskinan. Korupsi akan mempengaruhi faktor ekonomi dan pemerintahan yang kemudian akan berdampak kepada tingkat kemiskinan. Oleh sebab itu, hasil penelitian tersebut dapat dijadikan acuan untuk menilai seberapa besar keterkaitan tingkat korupsi dengan kemiskinan dalam suatu negara.

Negara-negara di Asia Tenggara mayoritas masih merupakan negara berkembang yang identik dengan tingkat kemiskinannya masih tinggi. Di dalam buletin yang ditulis oleh Bruno Jetin tentang kemiskinan di ASEAN dinyatakan bahwa di Laos, Filipina, Indonesia, dan Myanmar kemiskinan absolut masih menjadi masalah sosial yang signifikan. Maka dari itu, ASEAN membuat suatu komunitas yang diarahkan pada integrasi ekonomi kawasan yang implementasinya mengacu pada Asean Economic 
Community (AEC) Blueprint. Salah satu harapan dari AEC 2025, yaitu "Menghasilkan pertumbuhan ekonomi yang lebih tepat dan inklusif di ASEAN untuk mengurangi kesenjangan pembangunan, mengeliminasi apabila tidak mengurangi kemiskinan secara signifikan, mempertahankan tingkat pertumbuhan pendapatan per kapita, dan mempertahankan kelas menengah yang meningkat". Namun, harapan dari AED tersebut tentu tidak tercapai apabila korupsi masih terjadi di negara-negara Asia Tenggara. Berdasarkan Survey of Transparency International Corruption Perception Index (CPI) 2019, negara ASEAN, kecuali Malaysia, Singapura, dan Brunei Darussalam, masih memiliki skor dibawah 50 dari 100 yang artinya semakin rendah skor CPI maka semakin tinggi tingkat korupsi di negara tersebut. Dengan demikian, penelitian ini bermaksud untuk melihat gambaran korupsi dan kemisikan di negaranegara Asia Tenggara, menentukan model regresi data panel terbaik, dan melihat hubungan antara keduanya dari tahun 2015 sampai 2018.

\section{Metodologi}

\subsection{Bahan dan Data}

Sumber data pada penelitian ini adalah data sekunder 10 negara di Asia Tenggara dari tahun 2015 sampai 2018. Data yang digunakan berupa Corruption Perception Index (CPI) yang didapat dari Transparency International dan data Human Development Index (HDI) yang bersumber dari United Nations Development Programme (UNDP). Corruption Perception Index menggambarkan tingkat korupsi yang terjadi di negara tersebut. CPI berupa skala rasio dari 0 hingga 100 dimana semakin tinggi nilai CPI suatu negara maka semakin bersih negara tersebut dari tindak korupsi. Human Development Index pada penelitian ini digunakan menggambarkan tingkat kemiskinan di suatu negara. Hal ini dikarenakan HDI berfokus untuk mengukur prestasi pembangunan manusia yang dibangun atas tiga dimensi dasar kehidupan manusia yakni lamanya hidup, berpengetahuan dan memiliki standar kehidupan yang layak Jahan (2002). Apabila HDI suatu negara tinggi maka semakin rendah angka kemiskinan di negara tersebut.

\subsection{Metode Penelitian}

Analisis data yang digunakan untuk melihat hubungan antara korupsi dan kemiskinan pada penelitian ini menggunakan data panel yaitu gabungan dari data time series dan data cross section. Wanner dan Pevalin yang dikutip dalam Sembodo (2013) menyatakan bahwa regresi data panel merupakan sekumpulan teknik untuk memodelkan pengaruh variabel independen terhadap variabel dependen pada data panel. Menurut Basuki \& Yuliadi (2015), metode estimasi dengan menggunakan model regresi data panel dapat dilakukan dengan tiga pendekatan yakni:

\section{a. Common Effect Model}

Model ini merupakan pendekatan paling sederhana karena hanya menggabungkan data deret waktu (time series) dan data silang (cross section). Common Effect Model (CEM) tidak memperhatikan dimensi waktu maupun individu, sehingga diasumsikan sama dalam berbagai kurun waktu. CEM menggunakan pendekatan Ordinary Least 
Square (OLS) untuk menduga parameternya. Modelnya adalah sebagai berikut (Greene, 2000):

$$
\begin{array}{ll}
\text { dimana } \\
Y & : \text { Variabel dependen } \\
\alpha & : \text { Konstanta } \\
X & : \text { Variabel independen } \\
\beta & : \text { Koefisien regresi } \\
\varepsilon & : \text { Error terms } \\
\mathrm{t} & : \text { Periode waktu } \\
\mathrm{i} & : \text { Individu }
\end{array}
$$$$
\mathrm{Y}_{\mathrm{it}}=\alpha+\alpha_{\mathrm{i}}+\mathrm{X}_{\mathrm{it}} \beta_{\mathrm{it}}+\varepsilon_{\mathrm{it}}
$$

\section{b. Fixed Effect Model}

Asumsi pada model ini adalah perbedaan antar individu dapat diakomodasi dari perbedaan intersepnya. Fixed Effect Model mengestimasi data panel dengan menambahkan variabel dummy untuk menangkap perbedaan intersep antar data cross section. Namun, slope-nya tetap sama. Nama lain dari model ini adalah Least Squares Dummy Variable (LDSV). Persamaan model secara umum adalah sebagai berikut:

$$
Y_{i t}=\alpha+X_{i t} \beta_{i t}+\varepsilon_{i t}
$$

\section{c. Random Effect Model}

Random Effect Model mengasumsikan error saling berhubungan antar waktu dan individu. Pada model ini perbedaan intersep diakomodasi oleh error terms masingmasing data cross section. REM dapat menghilangkan heteroskedastisitas. Model ini menggunakan pendekatan Generalized Least Square (GLS). Modelnya adalah sebagai berikut:

\section{Dimana}

$$
\begin{gathered}
Y_{i t}=\beta_{i t}+v_{i t} \\
v_{i t}=c_{i}+d_{t}+\varepsilon_{i t}
\end{gathered}
$$

$\mathrm{c}_{\mathrm{i}} \quad$ : Konstanta yang bergantung pada $\mathrm{i}$

$d_{t} \quad$ : Konstanta yang bergantung pada $t$

Menurut Widarjono (2013) terdapat beberapa uji yang dapat digunakan untuk memilih model terbaik untuk mengestimasi data panel, yakni:

\section{a. Uji Chow}

Uji ini merupakan pengujian untuk membandingkan antara model fixed effect dan common effect dengan hipotesis sebagai berikut:

$\mathrm{H}_{0}$ : Model yang tepat untuk regresi data panel adalah model Common Effect Model

$\mathrm{H}_{1}$ : Model yang tepat untuk regresi data panel adalah model Fixed Effect Model

Statistik uji yang digunakan adalah uji $\mathrm{F}$ dengan statistik uji sebagai berikut (Baltagi, 2005) 
dalam hal ini

$$
F_{\text {hitung }}=\frac{\frac{\left(S S E_{1}-S S E_{2}\right)}{(n-1)}}{\frac{S S E_{2}}{(n t-n-k)}}
$$

$S S E_{1} \quad$ : Sum square error dari model common effect

$S S E_{2} \quad$ : Sum square error dari model fixed effect

$\mathrm{n}$ : Jumlah individu

nt : Perkalian antara time-series dengan cross-section

$\mathrm{k}$ : Menyatakan jumlah variabel independen

sedangkan nilai $F_{\text {hitung }} \sim F_{(n-1, n t-n-k)}$

dalam hal ini:

$\alpha$ : Tingkat signifikansi

$\mathrm{n}$ : Jumlah individu

nt : Perkalian antara time-series dengan cross-section

$\mathrm{k}$ : Menyatakan jumlah variabel independen

Apabila $\mathrm{F}$ hitung yang didapat lebih dari $\mathrm{F}$ tabel atau $p$-value kurang dari taraf signifikansi maka akan tolak hipotesis awal sehingga model yang terpilih adalah fixed effect model.

\section{b. Uji Hausmann}

Uji ini digunakan untuk memilih antara model random effect dan fixed effect. Hipotesisnya adalah:

$\mathrm{H}_{0}$ : Model yang tepat untuk regresi data panel adalah model Random Effect Model

$\mathrm{H}_{1}$ : Model yang tepat untuk regresi data panel adalah model Fixed Effect Model

Statistik uji yang digunakan adalah sebagai berikut (Baltagi, 2008)

$$
\begin{aligned}
W & =\hat{q}^{\prime}\left[\operatorname{var}\left(\hat{q}^{\prime}\right)\right]^{-1} \hat{q}^{\prime} \\
& =\left(\hat{\beta}_{M E T}-\hat{\beta}_{M E A}\right)^{\prime}\left[\operatorname{var}\left(\hat{\beta}_{M E T}-\hat{\beta}_{M E A}\right)\right]^{-1}\left(\hat{\beta}_{M E T}-\hat{\beta}_{M E A}\right)
\end{aligned}
$$

salam hal ini

$\hat{\beta}_{M E T} \quad$ : vektor estimasi slope model fixed effect

$\hat{\beta}_{M E A}$ : vektor estimasi slope model random effect

Apabila nilai $\mathrm{W}>\chi^{2}{ }_{(\alpha, k)}$ atau nilai $p$-value kurang dari taraf signifikansi maka model yang terpilih adalah fixed effect model.

\section{c. Uji Breusch-Pagan}

Menurut Rosadi (2011), uji Breusch Pagan digunakan untuk menguji apakah terdapat efek waktu, individu atau keduanya dengan hipotesis sebagai berikut: 
$\mathrm{H}_{0(1)}$ : Tidak ada efek individu dan waktu

$\mathrm{H}_{1(1)}$ : Ada efek individu dan waktu

$\mathrm{H}_{0(2)}$ : Tidak ada efek lintas individu

$\mathrm{H}_{1(2)}$ : Ada efek lintas individu

$\mathrm{H}_{0(3)}$ : Tidak ada efek lintas waktu

$\mathrm{H}_{1(3)}$ : Ada efek lintas waktu

Pada analisis menggunakan data panel tidak diperlukan uji asumsi klasik karena data panel dapat meminimalkan bias yang kemungkinan besar muncul dalam hasil analisis, memberi lebih banyak informasi, variasi, dan degree of freedom (Gujarati, 2012). Selain itu, data panel dapat digunakan untuk meminimalkan bias yang mungkin ditimbulkan oleh agregasi data individu. Keunggulan-keunggulan data panel menyebabkan data panel mampu mendeteksi dan mengukur dampak lebih baik, dimana hal ini tidak dapat dilakukan apabila hanya menggunakan metode cross section maupun time series saja. Panel data memungkinkan mempelajari lebih kompleks mengenai prilaku yang ada dalam model sehingga pengujian data panel tidak memerlukan uji asumsi klasik (Gujarati 1992 dalam Iswanto (2013)).

\section{Hasil dan Pembahasan}

\subsection{Gambaran Umum Korupsi dan Kemiskinan di Negara-Negara Asia Tenggara}

Angka CPI di negara-negara Asia Tenggara cenderung stabil dari tahun ke tahun. Berdasarkan Gambar 1, diperoleh angka CPI tertinggi diduduki oleh negara Singapura sebesar 85 pada tahun 2018, angka ini mengalami kenaikan dari tahun sebelumnya dimana pada tahun 2017 sebesar 84. Di peringkat kedua terdapat negara Malaysia dengan nilai CPI sebesar 47 pada tahun 2018 dimana angka ini cenderung turun dari tiga tahun sebelumnya dimana CPI Malaysia pada tahun 2015 berada pada nilai 50 . Indonesia menduduki peringkat tiga di Asia Tenggara dengan nilai CPI sebesar 38 pada tahun 2018.

Di sisi lain, angka Corruption Perception Indeks yang terendah berada di negara Kamboja. Angka CPI Kamboja cenderung stabil di kisaran 21 pada tahun 2015 sampai dengan 2017. Pada tahun 2018, angka CPI Kamboja berada pada peringkat terakhir diantara negara-negara Asia Tenggara yaitu sebesar 20. 


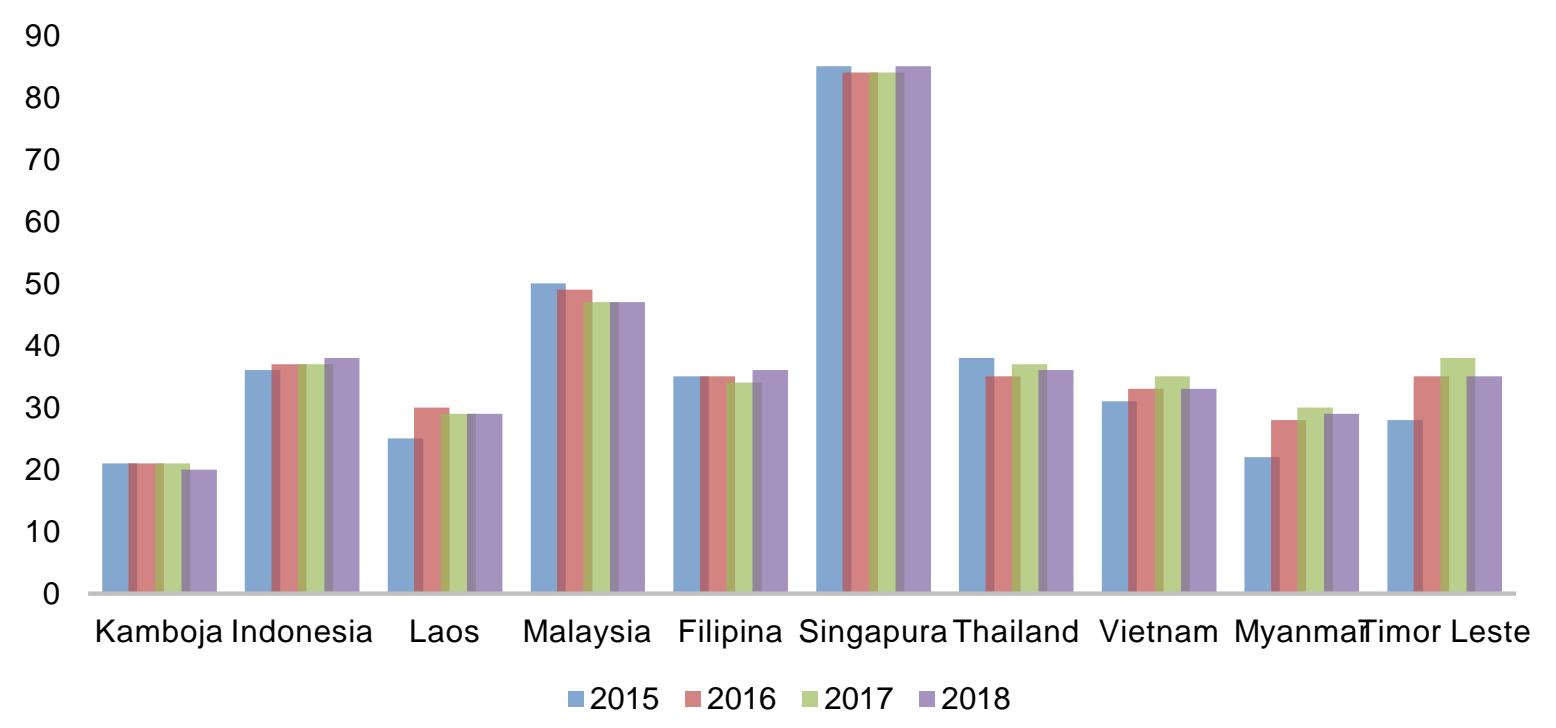

Gambar 1: Grafik angka Corruption Perception Indeks (CPI) negara-negara di Asia Tenggara tahun 2015-2018

Angka Human Development Index negara-negara di kawasan Asia Tenggara secara umum menunjukkan tren yang meningkat pada periode 2015-2018 (Gambar 2). Selama periode tersebut, negara Singapura selalu berada pada posisi pertama untuk angka HDI yang tertinggi. Hal ini dapat dilihat berdasarkan gambar di bawah ini dimana pada tahun 2018 diperoleh angka HDI tertinggi pada negara Singapura yaitu sebesar 0,935 . Selanjutnya di peringkat kedua yaitu negara Malaysia sebesar 0,802 dan peringkat ketiga yaitu Thailand sebesar 0,765 . Indonesia sendiri berada pada peringkat kelima di antara negara-negara ASEAN lainnya dengan angka HDI sebesar 0,704 . Di sisi lain, Myanmar berada pada posisi terakhir atau terendah dengan nilai sebesar 0,577 .

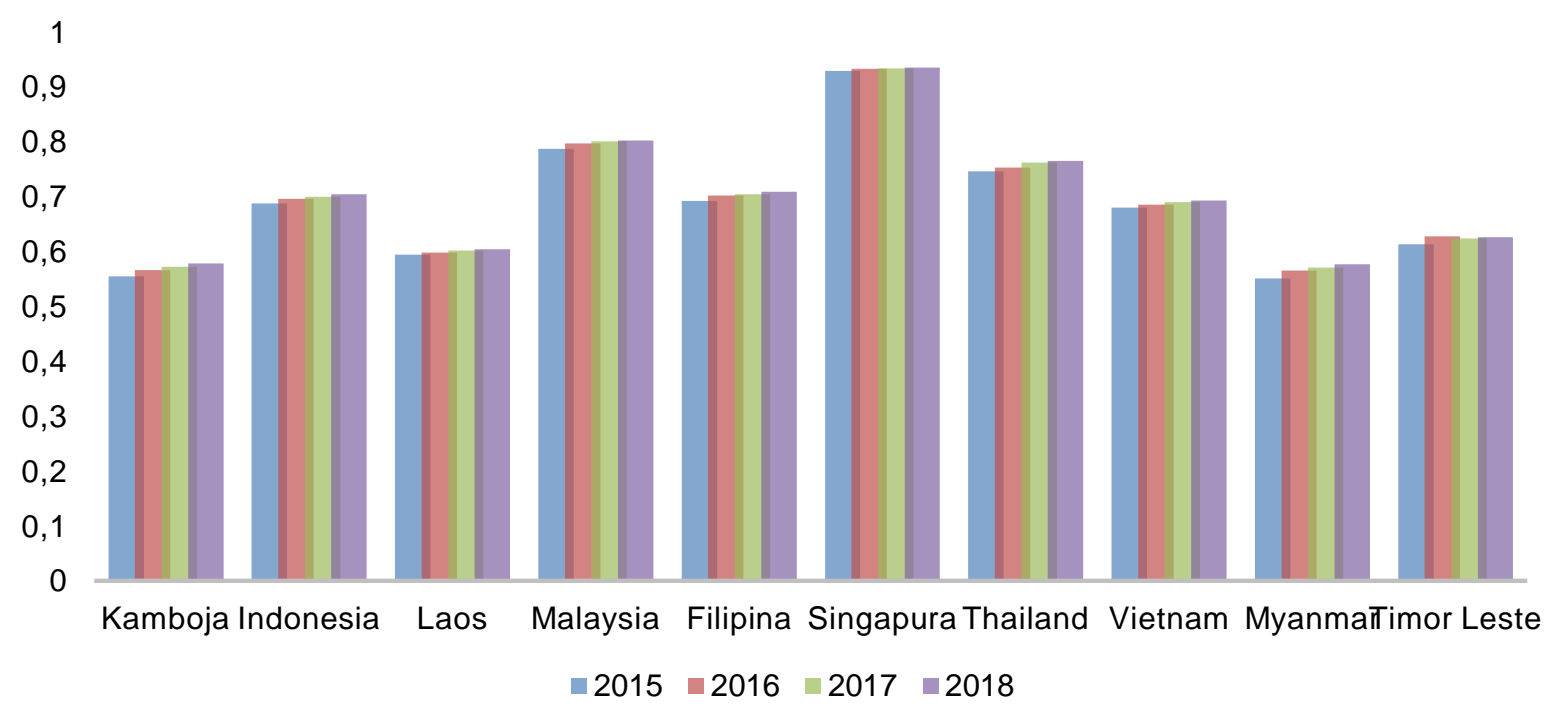

Gambar 2: Grafik angka Human Development Index (HDI) negara-negara di kawasan Asia Tenggara tahun 2015-2018 


\subsection{Hubungan Korupsi dan Kemisikan dengan Regresi Panel}

Human Development Index (HDI) di ASEAN akan diestimasi dengan regresi data panel. Sebelum dilakukan estimasi, terlebih dahulu ditentukan model regresi data panel yang sesuai. Beberapa model yang dapat dipilih antara lain common effect model (CEM), fixed effect model (FEM), dan random effect model (REM).

Uji Chow merupakan pengujian untuk melihat metode yang paling tepat digunakan antara CEM dan FEM. Perhitungan uji Chow didapatkan nilai $p$-value sebesar $<2,2 \times$ 【 10》^(-16) sehingga keputusan yang diambil adalah tolak $\mathrm{H}_{0}$. Artinya dengan tingkat signifikansi sebesar $5 \%$ terdapat cukup bukti bahwa FEM lebih tepat digunakan daripada CEM.

Selanjutnya dilakukan uji Hausman untuk menentukan metode mana yang paling tepat digunakan antara REM dan FEM. Berdasarkan hasil perhitungan uji Hausman didapatkan nilai $p$-value sebesar $<2,2 \times \llbracket 10 \rrbracket^{\wedge}(-16)$ sehingga keputusan yang diambil adalah tolak $\mathrm{H}_{0}$. Artinya dengan tingkat signifikansi sebesar $5 \%$ terdapat cukup bukti bahwa model FEM lebih tepat digunakan daripada REM. Dari hasil uji Chow dan uji Hausman dapat disimpulkan bahwa model yang paling tepat digunakan adalah fixed effect model.

Setelah didapatkan model yang paling tepat digunakan selanjutnya dilakukan pengujian untuk melihat adanya efek individu dan efek waktu.

Tabel 1: Breusch Pagan Test yang diperoleh.

\begin{tabular}{cc}
\hline Uji & p-value \\
\hline Efek dua arah & $2.092 \times 10^{-12}$ \\
Efek individu & $6.399 \times 10^{-13}$ \\
Efek waktu & 0.1507 \\
\hline
\end{tabular}

Berdasarkan Tabel 1 didapatkan nilai $p$-value yang kurang dari $5 \%$ untuk hipotesis pertama dan kedua, sehingga keputusannya tolak $\mathrm{H}_{0}$. Artinya untuk hipotesis pertama terdapat efek individual dan efek waktu, dan untuk hipotesis kedua terdapat efek individu. Sementara untuk hipotesis ketiga didapatkan nilai $p$-value yang lebih besar dari $5 \%$, sehingga keputusannya gagal tolak. Hal ini berarti tidak terdapat efek waktu.

Berdasarkan keseluruhan pengujian model yang dilakukan maka model terbaik yang digunakan pada penelitian adalah Fixed Effect Model dengan efek individu. Langkah berikutnya adalah membentuk model regresi data panel dan diperoleh model sebagai berikut.

$$
\widehat{\mathrm{Y}}_{\mathrm{it}}=\alpha_{\mathrm{i}}+0.001443 \mathrm{X}_{\mathrm{it}}
$$

Berdasarkan persamaan model regresi data panel di atas, dapat diketahui bahwa hubungan antara korupsi yang direpresentasikan dengan CPI dan kemiskinan yang direpresentasikan dengan HDI sejalan, yang berarti setiap peningkatan satu satuan CPI akan memberikan dampak kenaikan pada HDI sebanyak 0.001443 satuan. Hal ini sesuai dengan arti dari CPI itu sendiri, yakni semakin tinggi skor CPI maka semakin rendah tingkat korupsi yang kemudian akan berdampak pada HDI yang semakin tinggi yang artinya tingkat kemiskinannya semakin rendah. 
Tabel 2: Nilai efek individual pada fixed effect model.

\begin{tabular}{lc}
\hline Cross Section & Intercept Individu \\
\hline Filipina & 0.6512237 \\
Indonesia & 0.6435865 \\
Kamboja & 0.5377951 \\
Laos & 0.5587180 \\
Malaysia & 0.7270959 \\
Myanmar & 0.5266617 \\
Singapura & 0.8107650 \\
Thailand & 0.7038083 \\
Timur Leste & 0.5736673 \\
Vietnam & 0.6393609 \\
\hline
\end{tabular}

Selanjutnya adalah untuk mengetahui besar nilai yang pengaruh dari masingmasing objek individu berdasarkan Tabel 2 yang merupakan hasil dari nilai intercept setiap objek individu. Setelah didapatkan model regresi data panel maka selanjutnya dilakukan uji parsial terhadap variabel korupsi. Berdasarkan hasil uji parsial didapatkan nilai $p$-value sebesar 0.02123 sehingga keputusan yang diambil adalah tolak $\mathrm{H}_{0}$. Artinya dengan tingkat signifikansi sebesar $5 \%$ terdapat cukup bukti bahwa variabel korupsi berpengaruh signifikan terhadap variabel kemiskinan.

Hasil perhitungan $R$-Square dari model di atas sebesar 0,16986 atau $16,99 \%$. Hal ini berarti variabel korupsi dapat menjelaskan variabel kemiskinan sebesar 16,99\% dan sisanya sebanyak $83,01 \%$ dapat dijelaskan oleh variabel lain yang tidak termasuk dalam model.

\section{Simpulan}

Korupsi di negara-negara Asia Tenggara pada periode 2015-2018 cenderung stabil karena tidak mengalami perubahan yang signifikan. Kemiskinan yang direpresentasikan dengan data HDI di negara-negara Asia Tenggara pada periode 2015-2018 mengalami tren yang meningkat. Model regresi data panel yang lebih sesuai untuk pemodelan pengaruh tindak korupsi terhadap kemiskinan di negaranegara Asia Tengggara adalah fixed effect model dengan efek individual. Dari model tersebut dapat diketahui bahwa korupsi yang direpresentasikan melalui $\mathrm{CPI}$ dan kemiskinan yang direpresentasikan dengan HDI berbanding lurus yang berarti setiap peningkatan satu satuan CPI akan memberikan dampak kenaikan pada HDI sebanyak 0.001443 satuan

\section{Daftar Pustaka}

Baltagi, B. H. (2005). Econometrics Analysis of Panel Data (3rd ed.). England: John Wiley \& Sons Ltd.

Baltagi, B. H. (2008). Econometrics (4th ed.). Berlin (DE): Springer.

Basuki, A. T., \& Yuliadi, I. (2015). Ekonometrika Teori \& Aplikasi. Yogyakarta (ID): Mitra Pustaka Nurani. 
Chetwynd, E., Chetwynd, F., \& Spector, B. I. (2003). Corruption and Poverty: A Review of Recent Literature. Washington (US): Management Systems International.

Greene, W. H. (2000). Econometrics Analysis (3rd ed.). New Jersey (US): Prentice Hall.

Gujarati, D. (2012). Dasar-Dasar Ekonometrika. Jakarta (ID): Salemba Empat.

Iswanto. (2013). Pengaruh Efektivitas dan Efisiensi Pengelolaan Keuangan Daerah serta Sistem Pengendalian Intern Terhadap Keandalan Laporan Keuangan Pemerintah Daerah (Studi Empiris pada Pemerintah Kabupaten/Kota SeIndonesia) (PhD Thesis). Bandar Lampung (ID): Universitas Lampung.

Jahan, S. (2002). Measuring living standard and poverty: Human development index as an alternate measure [University of Massachusetts Political Economy Research Institute]. Retrieved January 27, 2020, from http://www.peri.umass.edu/fileadmin/pdf/gls_conf/glw_jahan.pdf

Rosadi, D. (2011). Ekonometrika dan Analisis Runtun Waktu Terapan dengan R. Yogyakarta (ID): Andi Offset.

Santoso, I. (2011). Memburu Tikut-Tikus Otonom. Yogyakarta (ID): Gava Media.

Sembodo, H. (2013). Pemodelan Regresi Panel pada Pendapatan Asli Daerah (PAD) dan Dana Alokasi Umum (DAU) Terhadap Belanja Daerah. Jurnal Mahasiswa Statistik, 1(4): 297-300.

Suparlan, P. (1993). Kemiskinan di Perkotaan. Jakarta (ID): Yayasan Obor Indonesia.

Transparancy International. (2020). How You Define Corruption? Retrieved from https://www.transparency.org/what-is-corruption\#define

Widarjono, A. (2013). Ekonometrika Pengantar dan Aplikasinya. Yogyakarta (ID): UPP STIM YKPN. 